Article

\title{
Disentangling the Roles of Topography, Patch, and Land Use on Conservation Trait Status of Specialist Birds in Marginal Forest Land Use Types
}

\author{
Petr Zasadil ${ }^{1, *(\mathbb{D})}$, Dušan Romportl ${ }^{2}$ and Jakub Horák ${ }^{3, *(1)}$ \\ 1 Faculty of Environmental Sciences, Czech University of Life Sciences Prague, Kamycka 1176, CZ-165 00 \\ Prague, Czech Republic \\ 2 Faculty of Science, Charles University in Prague, Vinicna 7, CZ-128 44 Prague, Czech Republic; \\ dusan@natur.cuni.cz \\ 3 Faculty of Forestry and Wood Sciences, Czech University of Life Sciences Prague, Kamycka 1176, CZ-165 00 \\ Prague, Czech Republic \\ * Correspondence: zasadil@fzp.czu.cz (P.Z.); jakub.sruby@gmail.com (J.H.)
}

Received: 6 December 2019; Accepted: 10 January 2020; Published: 14 January 2020

check for updates

\begin{abstract}
One of the main questions in ecology and conservation is how organisms are governed and affected by their traits within the context of abiotic gradients. The main question of our study addresses how patch, topography, and land use influence conservation trait status (rarity and red-list index) of birds generally, and of farmland and woodland specialists specifically, in marginal forest landscape types. We sampled birds from 68 traditional fruit orchards existing as remnants of agroforestry within the Pardubice Region of the Czech Republic during two consecutive years. We recorded 57 bird species, of which 31 species were forest dwellers and 16 farmland dwellers. Topographical predictors played the most significant role in influencing traits of the bird community as a whole. Farmland bird traits indicated the most balanced values, as they were significantly influenced by all studied predictor sets. Their responses nevertheless differed among the studied traits and also showed a more complex pattern because the values of interaction between some predictor categories were relatively high. Traits of woodland birds were most influenced by the patch configuration. We found that a structurally diversified marginal habitat type of traditional fruit orchards is able to promote a number of specialist species and also reveals important relationships between bird conservation traits and different predictor sets. Researchers should pay more attention to the conservation traits of birds and their interactions with environmental predictors. Furthermore, conservationists should be more attentive to the biodiversity value and sustainable management of traditional fruit orchards.
\end{abstract}

Keywords: agroforestry; bird conservation; traditional fruit orchard; rarity; red-list index; farmland specialist; woodland birds

\section{Introduction}

Birds occupy a very wide range of ecological positions. Many species are specialized in their ecological requirements [1]. Even within a single habitat type, such as a temperate deciduous forest, the niches occupied by different species are highly diverse, e.g., [2].

Animal conservationists today are facing the loss of bird species, which is in contrast to the previously accepted notion that it was inconceivable they ever could become threatened. In some cases, they have often been the subject of yearlong and unregulated hunting. This is, for instance, the case of farmland birds in Europe [3]. Extensive and long-term bird breeding atlas data have indicated that certain species of birds are gradually vacating their positions in areas that were formerly their 
strongholds. This puts formerly common species taxa at risk. In the worst case, they may become very rare birds [4].

Land managers are calling for answers regarding the main causes of the decline of formerly common species. Furthermore, they seek answers as to the extent that processes influencing the decline are interconnected [5]. Birds have mostly higher dispersal abilities than other taxa [6]. On the other hand, this ability, together with biotic interactions among birds, predisposes them generally to a necessity to utilize habitat patches on larger landscape scales [7]. Considering the generally negative impacts of fragmentation, which causes isolation for most organisms, this could apparently provide an advantage to birds. Nevertheless, as birds search for new territories during times when suitable habitats are lost, this might cause a decline in population densities of individual bird species [8], and especially of specialist species. An additional reason for the decline could be that many species are long-lived and repeated changes in the quality of their habitats during their lifetimes may cause a shortening of the average lifespan of the individual species or a change in species assemblages [9].

The pattern and configuration of habitat patches are thought to be among the most important factors influencing bird distributions. Patches that are highly diversified spatially are known to host more habitat specialists and more species at risk [10,11]. Traditional fruit orchards are relatively conspicuous man-made habitats, and they have high vertical and horizontal stratification compared to other agricultural habitats [12,13]. Orchards and similar landscape patches, such as scrublands, are widely distributed throughout the world and, in most cases, they constitute comparable, although rather marginal and fragmented, habitat types $[12,14]$. These landscape patches have high potential to host species that avoid the intensively used agricultural and forest land and also those that avoid late successional stages when woodlands are characterized by very closed canopies $[10,15]$.

Values other than species richness of birds remain less studied. Conservation trait status, such as rarity or level of threat, could be predicted to have high relevance for animal conservation. An important question is how organisms are governed by their traits within the context of abiotic environmental gradients [16].

In our study, we are interested in the question of whether birds respond differently regarding their conservation traits in traditional fruit orchards. Another of our aims is to reveal whether the responses of birds as a whole are different from the responses of specialist groups. The last but not least important aim of our study is to reveal the potential impact of different groups of environmental predictors on two different bird traits. We are interested in the extent of the influence of these predictors on bird traits and also to what extent the predictor categories interact, potentially affecting the traits independently and jointly with the other categories.

\section{Materials and Methods}

\subsection{Study Area}

The studied area is a central European (Czech Republic) rural agricultural landscape dominated by agricultural land. Nearly $60 \%$ of the landscape consisted of arable land and approximately $5 \%$ of permanent grasslands. One-fifth of the total area is covered by forests that are dominated by conifer plantations (Scots pine and Norway spruce), with only occasional island-like patches of mixed or deciduous stands (sessile and pedunculate oaks, European beech and hornbeam). Approximately $5 \%$ of the total is built-up area, mostly consisting of villages with fewer than 500 inhabitants. Only two towns are present in our study area: Choceň (50.0022 N, 16.2208 E) and Vysoké Mýto (49.9520 N, 16.1626 E). Both towns have less than 15,000 inhabitants.

We sampled a total of 68 sites within agroforestry habitats, these specifically being traditional fruit orchards. The orchards were characterized by regular distances between trees and almost regular tree crowns. The majority of trees were growing on vigorous rootstock and were grafted to the height of an adult man (i.e., approximately $1.8-2 \mathrm{~m}$ above the ground) [17]. The total area of traditional fruit orchards did not exceed $1 \%$ of the study area, and thus they represented marginal landscape patches. 


\subsection{Study Taxa, Specialization, and Trait Status}

Birds were counted from the center of each traditional fruit orchard. We first waited 5 min after entering until the birds settled down, and then all bird individuals seen and heard (with the exception of birds flying overhead) were recorded for 10-min intervals during each visit. Double counting was minimized by having a second observer keeping track of counted individuals while the first observer counted. The traditional fruit orchards studied were rather small and irregular landscape patches, and thus we optimized our counting for plots covering a maximum of $2500 \mathrm{~m}^{2}$. In this manner, we avoided the effect of oversampling in large orchards. Counting was carried out from dawn until late morning, only on days with suitable weather conditions. Each orchard was sampled three times during the most appropriate time for the study region, which means spring (April and May) in each of two years (2011 and 2012). That means each site was visited six randomly chosen times. The highest count from the six visits was taken as the resulting abundance of each species on each of the 68 study plots.

Disparate biodiversity indices, such as species richness, abundance, or diversity, are commonly used for evaluating interaction with abiotic gradients. For our analyses, we first divided the observed bird species into farmland and woodland specialists [18]. For a division of species according to rarity and red-list index status (termed "conservation trait status" for purposes of this study), we used a bird atlas popular in the Czech Republic [19]. For rarity, we used the value of unoccupied grid cells in the Czech Republic out of a total of 628 grid cells. For the red-list index, we weighted the species by the ranked values, denoting a constituent species red-list index using IUCN criteria $(\mathrm{LC}=1, \mathrm{NT}=2, \mathrm{VU}=$ 3). Hence, the red-list index is a sum of all species observed per number of their individuals and then multiplied by the value of their red-list status, e.g., 1 species with 2 individuals with LC is 2 , and 2 species with 1 individual and NT are 4.

\subsection{Study Predictors}

We considered three categories of predictors (Table 1) potentially influencing the bird species' traits. We use a total of 11 predictors to keep a comparable number of predictors for the three explanatory categories [20-22].

Table 1. Discrimination among predictor categories used in this study and their values (mean, standard error, minimum and maximum) in the 68 studied traditional fruit orchards.

\begin{tabular}{cccccc}
\hline Category & Predictor & Mean & SE & Min & Max \\
\hline Patch & Canopy openness & 78.1 & 2.2 & 16.0 & 100.0 \\
& Shrub coverage & 16.4 & 2.1 & 0.0 & 70.0 \\
& Surrounding & 2.6 & 0.1 & 1.0 & 4.0 \\
Land use & Rural and urban & 3.0 & 0.3 & 0.9 & 11.8 \\
& Forest & 19.2 & 1.5 & 4.6 & 51.5 \\
& Grassland & 12.5 & 0.6 & 3.6 & 31.1 \\
Topography & Arable & 60.0 & 1.9 & 27.2 & 78.5 \\
& Altitude & 324.3 & 4.5 & 268.8 & 411.3 \\
& Area & 6483.5 & 755.3 & 891.0 & $35,391.0$ \\
& Longitude & 50.0 & 0.0 & 49.9 & 50.0 \\
& Latitude & 16.2 & 0.0 & 16.1 & 16.3 \\
\hline
\end{tabular}

Patch-level predictors (i.e., patch scale) were measured directly inside the surveyed sites and selected with respect to the best reflection of spatial heterogeneity. Shrub coverage (percentages of shrub woody species that are higher than $0.5 \mathrm{~m}$ and lower than $2.5 \mathrm{~m}$ ) was used to represent vertical and horizontal patch heterogeneity. Canopy openness (\%) indicated the light conditions of the study patches and was measured using a Canon EF-8-15mm f/4L FishEye USM camera. For each site, photographs were taken on 25 May 2012 (i.e., under full foliage) at four representative locations within each site and at $1.5 \mathrm{~m}$ above ground level. All photographs were then evaluated using the software Gap Light Analyzer 2.0. The mean values from all locations were used in the analyses. The number of 
surrounding land use types (mentioned below) was used for the analyses because in such marginal patches, it reflected the direct, immediate effect of the surrounding environment, its heterogeneity, and the amount of potential drift fences.

The land use predictors (i.e., landscape scale) were drawn from the present topographic digital base map of the Czech Republic 1:10,000 (ZABAGED) and the Forest Cover Map [23] in GIS. The landscape level was measured for any particular surveyed site within a circle having radius $2263 \mathrm{~m}$ (from the center of the site), thereby taking in the surround 1608 ha. This distance was selected because it is known to best reflect the influence of land use types on birds in our study area [7]. The proportion of rural and urban land use type (\%) indicated the intensity of settlement and built-up areas in the surroundings of the studied sites. This predictor may influence the distribution of species with high tolerance to anthropogenically disturbed habitat types. The amount of permanent grasslands (\%) in the surroundings revealed a dominating agricultural habitat type with a low intensity of management (mowing and/or pasturing) compared to arable land. This land use category also described the understory conditions of traditional fruit orchards, and thus the potential overlap in requirements for some birds (e.g., ground-nesting species). The proportions of forest cover (\%) and arable fields (\%) in the surroundings reflected the dominant land use types in our study area. Furthermore, forests may partly mimic the overstory conditions of traditional fruit orchards (e.g., for birds nesting and foraging in crowns). As the land cover of forest and arable field land use types showed high collinearity, we used the forest for analyses regarding woodland specialists and the arable fields for farmland birds that prefer agricultural habitats, as well as the interaction of these predictors for analyses of the bird community as a whole.

The role of topography in ecology with respect to use at the optimal space continues to be debated and there is no consensus regarding which spatial scale is optimal for topographical predictors. Recent research has indicated that processes occurring at small spatial scales play important roles even at the large-scale level of an entire country, and vice versa [5]. We chose predictors that are commonly used in biogeography and ecology for describing organismal distribution (i.e., topographical scale). Altitude ( $m$ a.s.1.) indicated topographical heterogeneity, and it is mostly correlated with climatic conditions. Area $\left(\mathrm{m}^{2}\right)$ of the studied orchard was used to express the amount of potential habitat. Latitude and longitude, as the spatial terms ( $\mathrm{X}$ and $\mathrm{Y}$ ) derived from coordinates of the plot centers, were measured directly in the field using a Garmin Colorado 300.

\subsection{Statistical Analyses}

All statistical analyses were made using SAM v4.0 [24]. We used rarity and the red-list index as dependent variables. Any potential bias caused by collinearity among the studied predictors was controlled using a variance inflation factor (VIF $<2$ ). A linear regression analysis with three predictor sets (patch, land use, and topography) was used. Each set consisted of predictors from the categories in Table 1. The Gaussian distribution of the data was verified [25]. As we were interested in the contributions of particular predictor sets with respect to the studied dependent variable, we analyzed them using partial regression analyses [24]. This type of analysis revealed independent variance explained by particular predictor categories as well as variance explained jointly with other categories, e.g., [26].

\section{Results}

During the two study seasons, we observed 57 bird species $\left(\right.$ mean $_{\text {site }}=14.7 ; \mathrm{SE}=0.39 ; \mathrm{min}=7$; $\max =21$ ) in 68 studied traditional fruit orchards. Thirty-one species were forest dwellers and 16 were farmland specialists (Table 2). 
Table 2. Bird species of traditional fruit orchards in rural agricultural landscape of Pardubice Region, Czech Republic. Preferences, red-list categories, number of unoccupied grids in the Czech Republic (out of a total of 628 grids), number of individuals observed and heard, are indicated for presence at studied plots. $\mathrm{VU}=$ vulnerable, $\mathrm{NT}=$ near threatened.

\begin{tabular}{|c|c|c|c|c|c|}
\hline Species & Preference & Red-List & Grids & Individuals & Presence \\
\hline Acrocephalus palustris & General & & 52 & 4 & 4 \\
\hline Aegithalos caudatus & Woodland & & 37 & 1 & 1 \\
\hline Buteo buteo & Woodland & & 2 & 1 & 1 \\
\hline Carduelis cannabina & Farmland & & 26 & 4 & 4 \\
\hline Carduelis carduelis & Farmland & & 5 & 18 & 14 \\
\hline Carduelis chloris & Farmland & & 0 & 54 & 52 \\
\hline Certhia brachydactyla & Woodland & & 192 & 3 & 3 \\
\hline Columba palumbus & Woodland & & 2 & 11 & 10 \\
\hline Coturnix coturnix & Farmland & NT & 41 & 2 & 2 \\
\hline Cyanistes caeruleus & Woodland & & 1 & 93 & 67 \\
\hline Delichon urbicum & General & NT & 1 & 4 & 3 \\
\hline Dendrocopos major & Woodland & & 1 & 30 & 30 \\
\hline Emberiza citronella & Farmland & & 0 & 65 & 53 \\
\hline Erithacus rubecula & Woodland & & 1 & 26 & 26 \\
\hline Ficedula albicollis & Woodland & NT & 297 & 1 & 1 \\
\hline Ficedula hypoleuca & Woodland & NT & 287 & 2 & 2 \\
\hline Fringilla coelebs & Woodland & & 0 & 66 & 62 \\
\hline Garrulus glandarius & Woodland & & 3 & 18 & 18 \\
\hline Hippolais icterina & Woodland & & 38 & 17 & 17 \\
\hline Hirundo rustica & Farmland & & 1 & 45 & 33 \\
\hline Jynx torquilla & Woodland & VU & 196 & 7 & 7 \\
\hline Lanius collurio & Farmland & NT & 3 & 16 & 16 \\
\hline Lanius excubitor & Farmland & VU & 186 & 1 & 1 \\
\hline Locustella naevia & General & & 76 & 2 & 2 \\
\hline Motacilla alba & General & & 0 & 12 & 12 \\
\hline Motacilla cinerea & General & & 37 & 1 & 1 \\
\hline Muscicapa striata & Woodland & & 46 & 2 & 2 \\
\hline Oriolus oriolus & Woodland & & 170 & 1 & 1 \\
\hline Parus major & Woodland & & 0 & 79 & 68 \\
\hline Passer domesticus & General & & 4 & 47 & 28 \\
\hline Passer montanus & Farmland & & 36 & 73 & 38 \\
\hline Perdix perdix & Farmland & NT & 136 & 1 & 1 \\
\hline Periparus ater & Woodland & & 34 & 1 & 1 \\
\hline Phoenicurus ochruros & General & & 1 & 36 & 35 \\
\hline Phoenicurus phoenicurus & Woodland & & 31 & 4 & 4 \\
\hline Phylloscopus collybita & Woodland & & 3 & 56 & 53 \\
\hline Phylloscopus trochilus & Woodland & & 10 & 4 & 4 \\
\hline Pica pica & Farmland & & 24 & 10 & 10 \\
\hline Picus viridis & Woodland & & 40 & 2 & 2 \\
\hline Poecile montanus & Woodland & & 136 & 1 & 1 \\
\hline Poecile palustris & Woodland & & 49 & 14 & 14 \\
\hline Prunella modularis & Woodland & & 15 & 1 & 1 \\
\hline Pyrrhula pyrrhula & Woodland & & 68 & 1 & 1 \\
\hline Saxiola rubetra & Farmland & & 103 & 1 & 1 \\
\hline Serinus serinus & General & & 3 & 17 & 17 \\
\hline Sitta europaea & Woodland & & 1 & 2 & 2 \\
\hline Streptopelia decaocto & General & & 18 & 10 & 10 \\
\hline Streptopelia turtur & Farmland & & 32 & 2 & 2 \\
\hline Sturnus vulgaris & Farmland & & 3 & 93 & 44 \\
\hline Sylvia atricapilla & Woodland & & 1 & 55 & 52 \\
\hline Sylvia borin & Woodland & & 46 & 7 & 7 \\
\hline Sylvia communis & Farmland & & 12 & 21 & 20 \\
\hline Sylvia curruca & Farmland & & 14 & 26 & 25 \\
\hline Turdus merula & Woodland & & 1 & 70 & 68 \\
\hline Turdus philomelos & Woodland & & 1 & 35 & 35 \\
\hline Turdus pilaris & General & & 38 & 16 & 10 \\
\hline Turdus viscivorus & Woodland & & 42 & 2 & 2 \\
\hline
\end{tabular}


The relationship of the whole bird community with patch, topography, and land use categories was significant for rarity (whole model: $\left.R^{2}=0.32 ; p<0.01\right)$ and the red-list index $\left(R^{2}=0.32 ; p<0.01\right.$ ). For the whole bird community, topography played the most important role in the case of both studied traits. The influence of patch and land use was relatively weaker, and their effects were not significant (Figure 1).

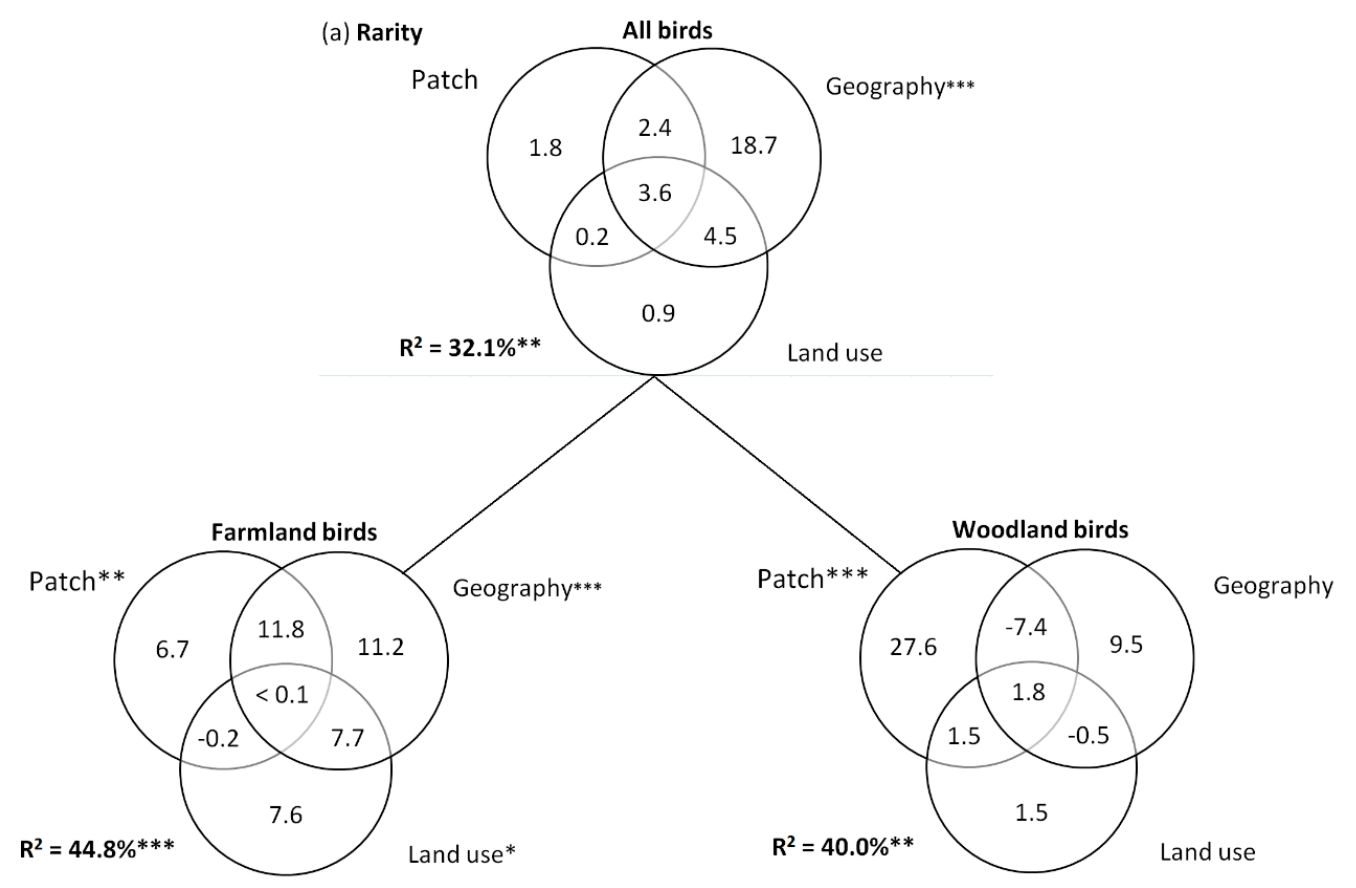

(b) Red list

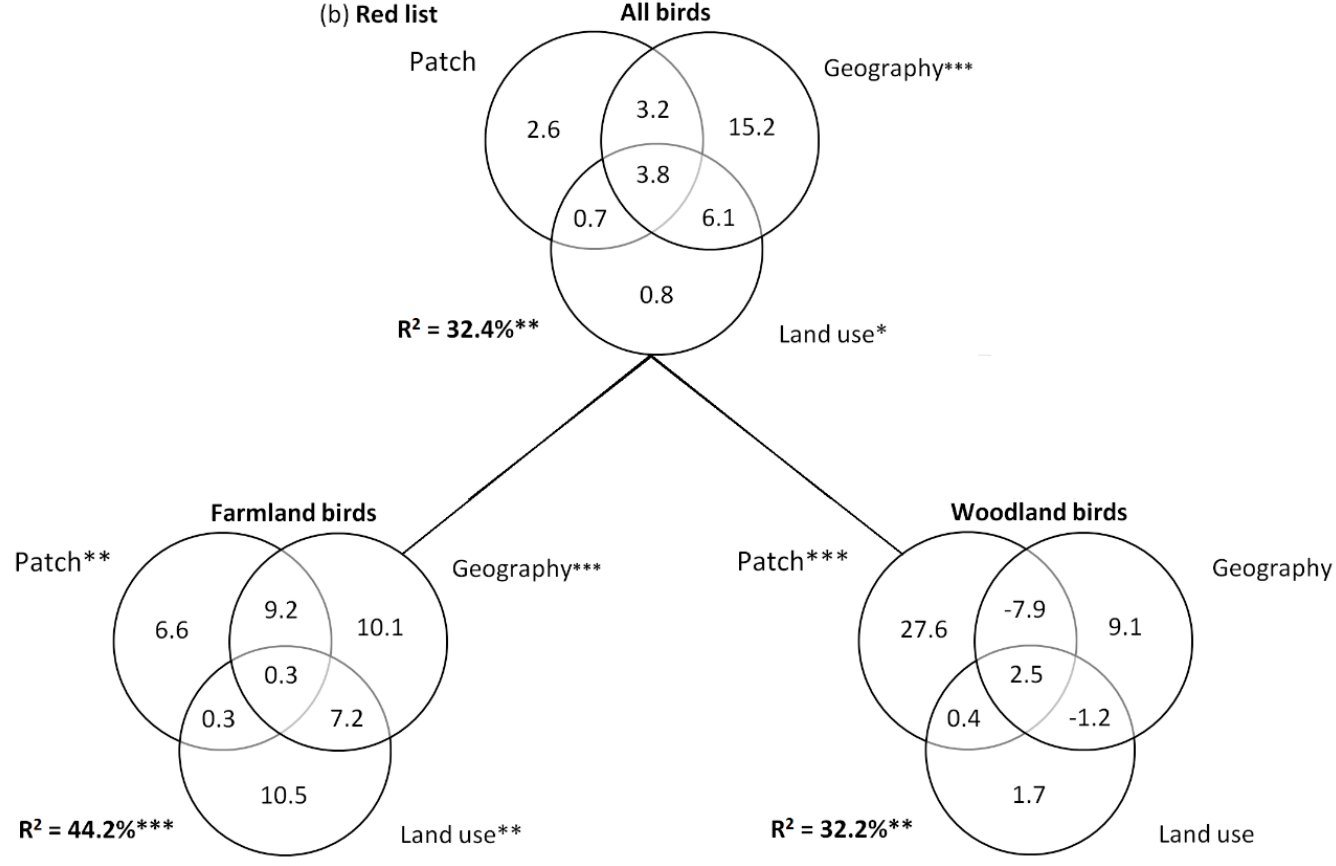

Figure 1. Results of the partial regression analyses for (a) rarity and (b) the red-list index of all birds, farmland specialists, and woodland specialists for the studied predictor categories representing patch, topography, and land use in traditional fruit orchards. Significance levels are ${ }^{*} p<0.05, * * p<0.01$, and ${ }^{* * *} p<0.001$. Only the net effects (independent $R^{2}$ ) of predictor levels can be tested statistically, while the overlapping sections (shared $R^{2}$ ) cannot be tested. Negative fractions are given by the correlation structure of the predictors, within which direct and indirect positive and negative effects of the individual predictors are combined [27]. 
A significant relationship was found also for farmland birds regarding rarity $\left(R^{2}=0.45 ; p<0.001\right)$ and the red-list index $\left(R^{2}=0.44 ; p<0.001\right)$. The traits of farmland birds were significantly influenced by all studied categories. Topography was the most significant, although that influence was at a lower level than determined for the overall bird community. Patch and land use revealed significant and stronger influences than was seen for the overall population of birds. In the case of rarity, the explained variance shared by patch and land use with topography was greater than their independent contributions. This showed that land use and patch categories were interconnected with topography in the case of farmland specialists (Figure 1).

Woodland birds also were found to have significant response for rarity $\left(R^{2}=0.40 ; p<0.01\right)$ and the red-list index $\left(R^{2}=0.32 ; p<0.01\right)$. Woodland specialists revealed different results than had been found in the previously described analyses. The traits of woodland birds were mostly influenced by the patch configuration of the traditional fruit orchards. In several instances, moreover, this predictor set showed negative values for shared variance explained by land use and topography (Figure 1).

\section{Discussion}

Several recent studies have indicated that some of the artificial habitat types, such as orchards, military training areas, and post-mining areas, could promote high diversity within bird communities $[7,10,11,28]$. During our brief analysis based on species numbers, we found that traditional fruit orchards hosted more specialist birds than opportunists. Moreover, woodland specialists occurred more frequently than did farmland specialists, and that coincides with the findings of Bailey et al. [12]. They showed that the number of woodland-preferring species and their abundance were greater than were those of other species. Specialist species were dominant, while bird species with no preference for particular habitats constituted $12.5 \%$ of the total population. This indicated that marginal land use types of traditional fruit orchards are suitable for species specialized in the dominant land use types within central Europe, which are forests and agricultural land. Furthermore, they also are occupied by forest and agricultural species, including threatened species like the Eurasian wryneck (Jynx torquilla) and common quail (Coturnix coturnix).

Farmland birds revealed the most contrasting results among the studied predictor sets. They showed higher values of jointly explained variance between and among sets than did woodland specialists and the bird communities as a whole. There was a very broad overlap between topography and patch level predictor sets, thereby indicating a large influence of interaction between these predictor categories on the traits of farmland birds [29], probably due to them being more sensitive to habitat quality as a result of agriculture intensification and other changes in agricultural landscapes $[4,30]$. Only slightly weaker effects were observed in the interaction of topography and land use. Although some previous studies have indicated different patterns (e.g., [31]) our results seem to be unexceptional. These results confirmed the coincidence with results from the agricultural-forest mosaic [32].

Nevertheless, low proportions were shared among all predictors for rarity. Weak interaction was observed between patch and land use. In this case, this might indicate good empirical discrimination between the predictors included in our categories (e.g., area in topography rather than patch).

The response of woodland specialists seemed to be the most simple. They were highly influenced by patch-level predictors, which is in agreement with the known fact that woodland birds occupy a very wide range of ecological positions in particular forest patches. Furthermore, bird species are specialized within a habitat type, and the positions occupied by different species are diverse $[1,2,18,19]$. This is mainly caused by vertical diversification of natural forests as primary habitat types for temperate bird assemblages. Habitat types of traditional orchards are thus most probably able to mimic high patch heterogeneity of forests. The relative proportions of shared components between predictor categories were relatively low, as has been indicated in studies dealing with forest birds (e.g., [33]). Nonsignificant responses to the topography and land use might be cited as exceptional because most studies have shown bird distributions to have a clumping tendency [34,35]. Namely, spatial geographical terms might have a clustering effect on observed birds [33]. The spatial structure in bird data may actually 
reflect distributions genuinely caused by a clumping of preferred or avoided habitats [32,35]. In our study, topographical predictors played the most significant role in the case of the whole bird community. This also indicated that topography might play a significant role on the broader extent of spatial scales than has commonly been indicated $[5,13]$. Furthermore, the effect of land use on birds is often prominent (e.g., [35]).

The results of the partial regression analyses for rarity and red-list index were very similar for all studied bird traits and the studied predictor categories. This is probably due to relatively low numbers of threatened species in the studied bird assemblage (only 8 out of a total 57 detected bird species, i.e., $14 \%$ of observed bird species, but only $5.5 \%$ of individuals recorded).

Although the number of threatened species is relatively low, yet this shows the high importance of old fruit orchards as a refugium of threatened species in the intensively used and changed agricultural landscape. It may mean that the conservation and suitable management of this habitat could help mitigate the decline of farmland bird specialists $[4,30]$ as well as to endangered woodland species.

\section{Conclusions}

We have presented here results that will contribute to disentangling the roles of topography, patch, and land use on conservation trait status of specialist birds in marginal and structurally diversified habitat types. We found that the diversified habitat of traditional fruit orchards is able to promote a relatively large number of specialist species and we also reveal ecologically important relationships between conservation trait status and different predictor sets.

Researchers in the future should pay more attention to the possible influence of interactions among and between predictors, and especially their categories. Furthermore, conservationists should be more attentive to the biodiversity value and sustainable management of traditional fruit orchards. The scale on which studied processes influence organisms, as well as the extent to which they are interconnected, is also of great importance because some predictors (e.g., topographical) might play a significant role within the broader extent of spatial scales than is commonly indicated. Nevertheless, our results should be interpreted with some caution because we were mainly interested in the influence of pooled environmental factors and we did not analyze trends of individual abiotic factors.

Author Contributions: Conceptualization, J.H. and P.Z.; methodology, P.Z., J.H. and D.R.; validation, J.H., D.R. and P.Z.; formal analysis, J.H.; investigation, J.H. and P.Z.; data curation, P.Z., J.H. and D.R.; writing-original draft preparation, J.H.; writing-review and editing, P.Z. and J.H.; visualization, J.H.; funding acquisition, P.Z. All authors have read and agreed to the published version of the manuscript.

Acknowledgments: We would like to thank Andrea Podavkova and Vendula Ludvikova for help in the field, as well as Allison Shardell for correction of English. This study was supported by Internal Grant Agency (CIGA no. 20154301), Czech University of Life Sciences Prague, the Internal Grant Agency (IGA no. B03/16), Faculty of Forestry and Wood Sciences, Czech University of Life Sciences, Prague and the Internal Grant Agency (IGA no. 2011421103136), Faculty of Environmental Sciences, Czech University of Life Sciences, Prague.

Conflicts of Interest: The authors declare no conflict of interest.

\section{References}

1. Rae, L.F.; Whitaker, D.M.; Warkentin, I.G. Multiscale impacts of forest degradation through browsing by hyperabundant moose (Alces alces) on songbird assemblages. Divers. Distrib. 2013, 20, 382-395. [CrossRef]

2. Müller, J.; Hothorn, T.; Pretzsch, H. Long-term effects of logging intensity on structures, birds, saproxylic beetles and wood-inhabiting fungi in stands of European beech Fagus sylvatica L. Forest Ecol. Manag. 2007, 242, 297-305.

3. Gates, S.; Donald, P.F. Local extinction of British farmland birds and the prediction of further loss. J. Appl. Ecol. 2000, 37, 806-820. [CrossRef]

4. Reif, J.; Voří̌̌ek, P.; Bejček, V.; Petr, J. Agricultural intensification and farmland birds: New insights from a central European country. Ibis 2008, 150, 596-605. [CrossRef]

5. McGill, B.J. Matters of scale. Science 2010, 328, 575-576. [CrossRef] 
6. Jackson, H.B.; Fahrig, L. Are ecologists conducting research at the optimal scale? Glob. Ecol. Biogeogr. 2015, 24, 52-63. [CrossRef]

7. Horak, J.; Peltanova, A.; Podavkova, A.; Safarova, L.; Bogusch, P.; Romportl, D.; Zasadil, P. Biodiversity responses to land use in traditional fruit orchards of a rural agricultural landscape. Agric. Ecosyst. Environ. 2013, 178, 71-77. [CrossRef]

8. Devictor, V.; Julliard, R.; Clavel, J.; Jiguet, F.; Lee, A.; Couvet, D. Functional biotic homogenization of bird communities in disturbed landscapes. Glob. Ecol. Biogeogr. 2008, 17, 252-261. [CrossRef]

9. Cepak, J.; Klňava, P.; Škopek, J.; Schröpfer, L.; Jelínek, M.; Hořák, D.; Formánek, J.; Zárybnický, J. Atlas Migrace Ptáků České Republiky a Slovenska; Aventinum: Prague, Czech Republic, 2008.

10. Reif, J.; Marhoul, P.; Č́žzek, O.; Konvička, M. Abandoned military training sites are an overlooked refuge for at-risk open habitat bird species. Biodiv. Conserv. 2011, 20, 3645-3662. [CrossRef]

11. Salek, M. Spontaneous succession on opencast mining sites: Implications for bird biodiversity. J. Appl. Ecol. 2012, 49, 1417-1425. [CrossRef]

12. Bailey, D.; Schmidt-Entling, M.H.; Eberhart, P.; Herrmann, J.D.; Hofer, G.; Kormann, U.; Herzog, F. Effects of habitat amount and isolation on biodiversity in fragmented traditional orchards. J. Appl. Ecol. 2010, 47, 1003-1013. [CrossRef]

13. Horak, J. Insect taxa with similar habitat requirements may differ in response to the environment in heterogeneous patches of traditional fruit orchards. J. Insect Conserv. 2014, 18, 637-642. [CrossRef]

14. Fortin, D.; Arnold, G.W. The influence of road verges on the use of nearby small shrubland remnants by birds in the central wheatbelt of Western Australia. Wildlife Res. 1997, 24, 679-689. [CrossRef]

15. Horak, J. Fragmented habitats of traditional fruit orchards are important for dead wood-dependent beetles associated with open canopy deciduous woodlands. Naturwissenschaften 2014, 101, 499-504. [CrossRef] [PubMed]

16. McGill, B.J.; Enquist, B.J.; Weiher, E.; Westoby, M. Rebuilding community ecology from functional traits. Trends Ecol. Evol. 2006, 21, 178-185. [CrossRef]

17. Janeček, V.; Rada, P.; Rom, J.; Horák, J. Rural artifacts in a city: Determinants of spatiotemporally continuous fruit orchards in an urban area. Urban For. Urban Green. 2019, 41, 33-38. [CrossRef]

18. Stastny, K.; Bejcek, V.; Vorisek, P.; Flousek, J. Population trends of farmland and woodland birds in the Czech Republic in 1982-2001 and their use as indicators. Sylvia 2004, 40, 27-48.

19. Stastny, K.; Bejcek, V.; Hudec, K. Atlas of Breeding Bird Distribution in the Czech Republic; Aventinum: Prague, Czech Republic, 2006.

20. Barbaro, L.; Rossi, J.P.; Vetillard, F.; Nezan, J.; Jactel, H. The spatial distribution of birds and carabid beetles in pine plantation forests: The role of landscape composition and structure. J. Biogeogr. 2007, 34, 652-664. [CrossRef]

21. Pysek, P.; Jarošík, V.; Hulme, P.E.; Kühn, I.; Wild, J.; Arianoutsou, M.; Winter, M. Disentangling the role of environmental and human pressures on biological invasions across Europe. Proc. Natl. Acad. Sci. USA 2010, 107, 12157-12162. [CrossRef]

22. Blanchet, F.G.; Legendre, P.; Borcard, D. Forward selection of explanatory variables. Ecology 2008, 89, 2623-2632. [CrossRef]

23. European Commision. Forest Cover Map. 2019. Available online: http://forest.jrc.ec.europa.eu/. (accessed on 6 December 2019).

24. Rangel, T.F.; Diniz-Filho, J.A.F.; Bini, L.M. SAM: A comprehensive application for spatial analysis in macroecology. Ecography 2010, 33, 46-50. [CrossRef]

25. Zuur, A.F.; Ieno, E.N.; Elphick, C.S. A protocol for data exploration to avoid common statistical problems. Methods Ecol. Evol. 2010, 1, 3-14. [CrossRef]

26. Horak, J.; Pavlicek, J. Tree level indicators of species composition of saproxylic beetles in old-growth mountainous spruce-beech forest through variation partitioning. J. Insect Conserv. 2013, 17, 1003-1009. [CrossRef]

27. Legendre, P.; Legendre, L. Numerical Ecology, 2nd ed.; Elsevier: Amsterdam, The Netherlands, 1998.

28. Horak, J.; Rom, J.; Rada, P.; Safarova, L.; Koudelkova, J.; Zasadil, P.; Hald, J.P.; Holusa, J. Renaissance of a rural artifart in a city with a million people: Biodiversity responses to an agroforestry restoration in a large urban traditional fruit orchard. Urban Ecosyst. 2018, 21, 263-270. 
29. Cushman, S.A.; McGarigal, K. Hierarchical, multi-scale decomposition of species-environment relationships. Landsc. Ecol. 2002, 17, 637-646. [CrossRef]

30. Reif, J.; Vermouzek, Z. Collapse of farmland bird populations in an Eastern European country following its EU accession. Conserv. Lett. 2019, 12, e12585. [CrossRef]

31. Freemark, K.E.; Kirk, D.A. Birds on organic and conventional farms in Ontario: Partitioning effects of habitat and practices on species composition and abundance. Biol. Conserv. 2001, 101, 337-350. [CrossRef]

32. Heikkinen, R.K.; Luoto, M.; Virkkala, R.; Rainio, K. Effects of habitat cover, landscape structure and spatial variables on the abundance of birds in an agricultural-forest mosaic. J. Appl. Ecol. 2004, 41, 824-835. [CrossRef]

33. Hobson, K.A.; Kirk, D.A.; Smith, A.R. A multivariate analysis of breeding bird species of western and central Canadian boreal forests: Stand and spatial effects. Ecoscience 2000, 7, 267-280. [CrossRef]

34. Haila, Y.; Nicholls, A.O.; Hanski, I.K.; Raivio, S. Stochasticity in bird habitat selection: Year-to-year changes in territory locations in a boreal forest bird assemblage. Oikos 1996, 76, 536-552. [CrossRef]

35. Siriwardena, G.M.; Crick, H.Q.P.; Baillie, S.R.; Wilson, J.D. Agricultural land-use and the spatial distribution of granivorous lowland farmland birds. Ecography 2000, 23, 702-719. [CrossRef]

(C) 2020 by the authors. Licensee MDPI, Basel, Switzerland. This article is an open access article distributed under the terms and conditions of the Creative Commons Attribution (CC BY) license (http://creativecommons.org/licenses/by/4.0/). 